\title{
Efektivitas Edukasi Konsep Diri Untuk Meningkatkan Pengetahuan Perkembangan Remaja
}

\author{
Yosiana Muftiaingrum ${ }^{1}$, Rr. Sri Endang Pujiastuti ${ }^{2}$, Sawab $^{2}$ \\ ${ }^{1}$ Mahasiswa Program Studi S1 Terapan Poltekkes Kemenkes Semarang \\ ${ }^{2}$ Dosen Jurusan Keperawatan Poltekkes Kemenkes Semarang \\ Corresponding author: Yosianamuftianingrum@gmail.com
}

\begin{abstract}
Background: The role of adolescents will be balanced if the task of adolescent development goes well. Adolescents are required to change their attitudes and behavior in accordance with applicable norms. While a person's behavior is much influenced by his concept. Therefore education about self-concept can be done as a means to help adolescents recognize themselves in the process of development.

Purpose: To determine the effectiveness of self-concept education to improve knowledge of adolescent development.

Methods: The study used a research design Quasy Experiment with non randomized contol group pretest posttest. This study uses two groups. The sample of this study is adolescents aged 12-14 years. The sampling technique used is non probability sampling with a purposive sampling method, and consisted of 94 sample / groups. Mann-whitney was conducted to determine the effect of self-concept education in increasing knowledge of adolescent development in the treatment and control groups.

Results: Based on the results of the mann-whitney obtained $p$ value $=0.000$ ( $p<0.005$ ), which means that $\mathrm{H} 0$ is rejected so that there is an effect of self-concept education on increasing knowledge of adolescent development. Conclusion: Based on the research, it was found that there was a significant effect on the effect of self-concept education on increasing the knowledge of adolescent development in SMP N 21 Semarang. Educating self-concept in early adolescents is expected so that adolescents understand more about the concepts in themselves according to the stage of their development.
\end{abstract}

Keywords: education; self concept; developmental knowledge; adolescent

\section{LATAR BELAKANG}

Remaja merupakan masa peralihan dari masa anak-anak dengan masa dewasa. Menurut WHO, usia remaja berlangsung pada rentang usia 10-19 tahun. Menurut Hurlock (dalam Herlina, 2013), remaja dibagi menjadi dua bagian yaitu remaja awal dan remaja akhir. Remaja awal dengan rentang usia 13-17 tahun. Dan remaja akhir pada usia 16/ 17-18 tahun. Pada remaja awal terjadi suatu peralihan, dimana mereka merasa bukan lagi seorang anak-anak tetapi juga tidak sebagai orang dewasa. 
Remaja menurut BKKBN (2016) adalah individu dengan rentang usia 10-24 tahun, saat ini tercatat penduduk remaja di indonesia dengan rentang usia 10-24 tahun adalah 66,3 juta jiwa dari total penduduk 258,7 juta. Menurut BPS (2017), di jawa tengah sendiri memiliki populasi penduduk 34.257.865 jiwa. Tercatat total penduduk remaja dengan rentang usia 10-14 tahun sebesar 2.780 .813 jiwa dengan presentase $8,11 \%$ dari total penduduk. Sedangkan pada rentang usia 15-19 tahun sebesar 2.821.534 jiwa dengan presentase 8,23\% dari total penduduk. Di Kota Semarang sendiri menurut BPS pada bulan Agustus 2017 tercatatat ada 119.633 jiwa penduduk remaja dengan rentang usia 10-14 tahun dengan peresentase 7,68\% dari total penduduk. Dan 147.549 jiwa penduduk remaja dengan rentang usia 15-19 tahun dengan presentase 9,48\% dari total penduduk 1.555.984 jiwa. dari gambaran tersebut remaja memiliki peran yang penting dalam susunan masyarakat.

Konsep diri merupakan cara individu dalam memandang dirinya sendiri. konsep diri terdiri dari gambaran diri, ideal diri, harga diri, peran diri, dan identitas diri. Erickson (Upton, 2012), proses perkembangan remaja dari sisi psikososial pada usia 12-18 tahun terjadi konflik dasar pada identitas dan kebingungan peran. Hasil penelitian dari Kumalasari dan Wijayanti (2013) tentang konsep diri pada anak jalanan usia remaja mendapatkan hasil bahwa dari sisi peran $11 \%$ memiliki konsep diri baik, $67 \%$ dengan kategori cukup, dan $22 \%$ dengan kategori kurang. Sedangkan pada sisi identitas diri menunjukkan angka 28\% dengan kategori baik, $61 \%$ dengan kategori cukup. dan $11 \%$ dengan kategori kurang. Tercermin bahwa masih ada remaja yang memiliki identitas diri dan peran diri yang kurang baik. Dampaknya remaja cenderung meniru perilaku dan bergantung dengan orang lain.

Penampilan fisik mempengaruhi konsep diri remaja. Hal ini terjadi Karena adanya perubahan fisik secara signifikan dan cepat, yang diikuti dengan perubahan sikap serta perilaku remaja. Dalam penelitian Gita Kania Saraswatia, Zulpahiyana, Siti Arifah (2015) terhadap konsep diri remaja di SMP N 13 Yogyakarta mendapatkan hasil $p=$ 0,000 (<0,005), menunjukkan bahwa penampilan fisik mempengaruhi konsep diri seseorang.

Perubahan-perubahan fisik yang terjadi pada remaja akan mempengaruhi perkembangan yang dijalani oleh remaja kearah positif atau negatif. Sehingga hal tersebut akan mempengaruhi konsep diri pada remaja. Hasil penelitian Widiarti (2017) pada siswa SMP se kota Yogyakarta menunjukan bahwa 50,6\% siswa memiliki konsep diri yang tinggi dan 49,4\% memiliki konsep diri yang rendah. Dapat disimpulkan bahwa presentase siswa dengan konsep diri tinggi dan rendah seimbang. Tercermin bahwa masih ada remaja yang memiliki konsep diri yang rendah, sehingga remaja belum memahami dirinya sendiri secara rinci.

Konsep diri pada remaja juga dipengaruhi oleh jenis kelamin. Pada umumnya remaja perempuan memiliki konsep diri yang lebih tinggi dibandingkan dengan remaja lakilaki. Dalam penelitian Lawrence dan Vimala (2013), ditemukan perbedaan konsep diri remaja antara laki-laki dan perempuan di sekolah. Remaja perempuan memiliki nilai mean $=20,37$ sedangkan remaja laki-laki memiliki nilai mean $=19,04$. Membuktikan 
bahwa saat ini remaja perempuan memiliki tingkat kepercaayan diri yang lebih di bandingkan dengan remaja laki-laki.

Remaja awal memiliki perkembangan kognisi yang belum sempurna. Menurut Ali dan Asrori (2012) perkembangan kognisi remaja berkaitan erat dengan pelaksanaan tugastugas perkembangann. Semakin matang perkembangan kognisi remaja semakin membantu pelaksanaan tugas-tugas perkembangan remaja. Havighrust (Ardiyanti, 2017) menyatakan bahwa ada 10 tugas-tugas perkembangan yang harus dilewati oleh remaja untuk dapat melangkah ke fase berikutnya.

Tugas-tugas perkembangan pada remaja banyak dipengaruhi oleh faktor-faktor disekitarnya. Perkembangan fisik dan psikis remaja dapat mempengaruhi kelancaran dalam pelaksanaan tugas perkembangan remaja. Menurut penelitian Maiyuniati (2014) faktor perkembangan fisik pada remaja mempengaruhi kelancaran pelaksanaan tugas perkembangan remaja memiliki rata-rata 19,56 dengan kriteria sedikit. Sedangkan kurang lancarnya pelaksanaan tugas perkembangan remaja memiliki kategori cukup banyak dengan rata-rata 28,80 pada faktor psikis. Remaja disini tidak memiliki tempat yang jelas, mereka berada di fase mencari jati diri atau fase topan dan badai. Remaja tidak termasuk anak-anak dan juga belum secara penuh disebut sebagai orang dewasa. sehingga remaja sendiri belum mampu memaksimalkan fungsi fisik dan psikis yang ada dalam dirinya.

Peran remaja akan seimbang apabila tugas perkembangan remaja berjalan dengan baik. untuk itu remaja dituntut untuk mengubah sikap dan perilakunya. Sedangkan tingkah laku seseorang banyak di pengaruhi oleh konsep dirinya. Menurut Ali dan Asrori (2008) Penampilan fisik, Perubahan fisik, perubahan kognisi dan pencapaian tugastugas perkembangan merupakan suatu proses dari perkembangan remaja. Erickson ( Ardiyanti, 2017) menyatakan bahwa konsep diri tidak akan lepas dari proses tumbuh kembang kepribadian individu. Sedangkan pada remaja awal sedang mengalami proses dalam mengenali diri sendiri, Sehingga perlu di kenalkan tentang apa itu konsep diri. Oleh karena itu pendidikan kesehatan tentang konsep diri dapat di lakukan sebagai sarana untuk membantu remaja mengenali diri sendiri didalam proses perkembangannya.

\section{TUJUAN}

Penelitian ini bertujuan untuk mengetahui efektifitas edukasi konsep diri untuk meningkatkan pengetahuan perkembangan remaja di SMP N 21 Semarang

\section{METODE}

Penelitian ini menggunakan desain penelitian quasy eksperimen dengan rancangan non randomized contol group pretest postest design. Penelitian ini dilakukan di SMP N 21 Semarang pada tanggal 5 Maret 2019 dan 22 Maret 2019. Populasi pada penelitian adalah siswa-siswi kelas VII SMP N 21 Semarang tahun 2018/2019 sebanyak 288 siswa. Teknik sampling dengan non-probability sampling dengan purposive sampling. apabila subyek dalam penelitian besar dan lebih dari 100 maka dapat diambil antara 10$15 \%$ atau 20-55\% (Arikunto, 2008). Penelitian ini mengambil sampel 30\% dari populasi, sehingga didapatkan responden sebanyak 94 orang setiap kelompok. 
Intervensi dilakukan pada dua kelompok. Kelompok perlakuan diberikan edukasi konsep diri berupa pendidikan kesehatan dengan media booklet, PPT, dan video.

Sedangkan pada kelompok kontrol edukasi diberikan dengan di berikan booklet tentang konsep diri. Kriteria inklusi pada penelitian ini adalah siswa aktif kelas VII, berusia 1214 tahun. Instrumen pada penelitian ini adalah pengetahuan kuesioner Perkembangan Remaja. Analisa data dengan menggunakan uji wilcoxon dan uji mann-whitney dikarenakan data berdistribusi tidak normal.

\section{HASIL}

\section{Karakteristik Responden}

Tabel 1 distribusi frekuensi karakteristik responden berdasarkan usia (n=94)

\begin{tabular}{ccccccccc}
\hline & \multicolumn{3}{c}{ Kelompok Pelakuan } & \multicolumn{3}{c}{ Kelompok Kontrol } \\
\cline { 2 - 9 } Variabel & Mean & SD & Min & Modus & Mean & SD & Min & Modus \\
& Median & & Max & & Median & Max & \\
\hline \multirow{2}{*}{ Usia } & 12,47 & 0,502 & $12(53,2 \%)$ & 12 & 12.55 & 0,541 & $12(46,8 \%)$ & $13(51,1 \%)$ \\
& 12,00 & & $13(46,8 \%)$ & $(53,2 \%)$ & 13,00 & & $14(2,1 \%)$ & \\
\hline
\end{tabular}

Berdasarkan tabel 1 didapatkan rata-rata usia responden pada kelompok perlakuan 12,47 tahun. Usia termuda responden 12 tahun, tertua 13 tahun. Usia terbanyak responden yaitu 12 tahun. Sedangkan pada kelompok konrol didapatkan rata-rata usia12,55 tahun,. Usia termuda responden 12 tahun, tertua 14 tahun. Usia terbanyak yaitu 13 tahun.

Tabel 2 distribusi frekuensi karakteristik responden berdasarkan jenis kelamin

\begin{tabular}{ccccc}
\hline Variabel & \multicolumn{2}{c}{$\begin{array}{c}\text { Kelompok } \\
\text { Perlakuan }\end{array}$} & \multicolumn{2}{c}{ Kelompok Kontrol } \\
\cline { 2 - 5 } (jenis kelamin) & F & $\%$ & $\mathrm{f}$ & $\%$ \\
\hline Laki-laki & 37 & 30,4 & 34 & 36,2 \\
Perepuan & 57 & 60,6 & 60 & 63,8 \\
\hline
\end{tabular}

Berdasarkan tabel 2 didapatkan hasil pada kelompok perlakuan sebanyak 37 responden berjenis kelamin laki-laki dengan presentase 30,4\%, dan sisanya 57 responden berjenis kelamin perempuan dengan presentase $60,6 \%$. Sedangkan pada kelompok kontrol didapat 34 responden berjenis kelamin laki-laki, dan 60 responden berjenis kelamin perempuan dengan presentase $63,8 \%$. 


\section{Gambaran Skor Pretest Dan Posttest Tingkat Pengetahuan Perkembangan Remaja Pada Kelompok Perlakuan Dan Kelompok Kontrol}

Tabel 3 skor pre test dan post test tingkat pengetahuan perkembangan remaja pada kelompok perlakuan $(n=94)$

\begin{tabular}{ccccc}
\hline \multirow{2}{*}{ Variabel } & \multicolumn{4}{c}{ KELOMPOK PERLAKUAN } \\
\cline { 2 - 5 } & $\begin{array}{c}\text { Mean } \\
\text { Median }\end{array}$ & SD & Min & Modus \\
& 103,77 & & Max & \\
\hline Pretest & 103,00 & 7,656 & 125 & 99 \\
& 110.78 & & 87 & \\
Postest & 111,00 & 8,184 & 129 & 118 \\
& 7,51 & & 1 & 3 \\
Selisih & 5,50 & 5,618 & 27 & 3 \\
& & & & \\
\hline
\end{tabular}

Berdasarkan tabel 3 didapatkan rata-rata skor pre test tingkat pengetahuan responden pada kelompok perlakuan 103,77 dengan median 103,00. Skor terendah responden 86, tertinggi 125 dan skor yang paling banyak diperoleh yaitu 99. Sedangkan rata-rata skor post test tingkat pengetahuan perkembangan remaja responden pada kelompok perlakuan 110,78 dengan median 111,00. Skor terendah 87, skor tertinggi 129 dan skor terbanyak yaitu 118. Selisih pre test dan post test pada kelompok perlakuan diperoleh rerata 7,51. Skor selisih terendah 1 dan tertinggi 27, dan selisih terbanyak yaitu 3 .

Tabel 4 Skor pre test dan post test tingkat pengetahuan perkembangan remaja pada kelompok kontrol $(n=94)$

\begin{tabular}{ccccc}
\hline \multirow{2}{*}{ Variabel } & \multicolumn{4}{c}{ KELOMPOK KONTROL } \\
\cline { 2 - 5 } & $\begin{array}{c}\text { Mean } \\
\text { Median }\end{array}$ & SD & Min & Modus \\
& 103,57 & 7,470 & 90 & 107 \\
Pretest & 103,00 & & 122 & 107 \\
& 104.54 & 8.045 & 88 & \\
Post test & 105.00 & & 122 & 0 \\
& 0,97 & 4,277 & -16 & \\
Selisih & 1,00 & & 14 & \\
& & & &
\end{tabular}

Berdasarkan tabel 4 didapatkan rata-rata skor pre test perkembangan remaja 103,57 dengan median 103,00. Skor terendah responden 90, tertinggi 122 dan skor paling banyak yaitu 107. Sedangkan untuk rata-rata skor post test tingkat pengetahuan perkembangan remaja responden pada kelompok kontrol 104,54, dengan median 105,00. Skor terendah 88, skor tertinggi 122 dan skor terbanyak yaitu 107. Selisih pre test dan post test pada kelompok kontrol diperoleh rerata 0,97, median 1,00. Skor selisih terendah -16 dan tertinggi 14, dan selisih terbanyak yaitu 0 . 


\section{Perbedaan Tingkat Pengetahuan Perkembangan Remaja Pada Kelompok Perlakuan Dan Kelompok Kontrol}

Tabel 5 analisis uji wilcoxon skor tingkat pengetahuan pre test dan post test pada kelompok perlakuan dan kelompok kontrol $(N=188)$

\begin{tabular}{cccc}
\hline Kelompok & Sebelum & Sesudah & \multirow{2}{*}{ p value } \\
\cline { 2 - 3 } & $\overline{\mathbf{x}} \pm \mathrm{SD}$ & $\overline{\mathbf{x}} \pm \mathrm{SD}$ & \\
\hline Perlakuan & $103,77 \pm 7,656$ & $110,78 \pm 8,184$ & 0,000 \\
Kontrol & $103,57 \pm 7,470$ & $104,54 \pm 8,045$ & 0,015 \\
\hline
\end{tabular}

Hasil tabel 5 menunjukan hasil Analisis data didapatkan rata-rata skor tingkat pengetahuan pre atau sebelum perlakuan yaitu 103,77 dengan standar deviasi 7,656 dan rata-rata post atau setelah perlakuan yaitu 110,78 dengan standar deviasi 8,84. Hasil uji analisis statistika didapatkan $\mathrm{p}$ value $=0.000(<0.05)$ yang berarti terdapat pengaruh edukasi konsep diri untuk meningkatkan pengetahuan perkembangan remaja yang digambarkan dengan adanya perbedaan mean yang signifikan antara skor pre dan post.

Rata-rata skor pengetahuan pada kelompok kontrol pre atau sebelum perlakuan yaitu 103,57 dengan standar deviasi 7.470, sedangkan rata-rata skor pengetahuan setelah perlakuan pada kelompok kontrol yaitu 104,54 dengan standar deviasi 8,045. Hasil uji analisis statistika didapatkan $p$ value $=0.015(<0.05)$ yang berarti ada pengaruh yang digambarkan dengan adanya perbedaan mean antara skor pre dan post, namun tidak signifikan. Efektivitas Skor Tingkat Pengetahuan Kelompok Perlakuan Dan Kelompok
Kontrol Dalam Meningkatkan Pengetahuan Perkembangan Remaja

Tabel 6 hasil analisis uji mann-whitney skor pengetahuan pada kelompok perlakuan dan kelompok kontrol perkembangan remaja

\begin{tabular}{lccc}
\hline \multirow{2}{*}{ Variabel } & Perlakuan & Kontrol & p value \\
\cline { 2 - 3 } & $\Delta \overline{\mathbf{x}} \pm \mathrm{SD}$ & $\Delta \overline{\mathbf{x}} \pm \mathrm{SD}$ & \\
\hline $\begin{array}{l}\text { Pengetahuan } \\
\text { Perkembangan } \\
\text { Remaja }\end{array}$ & $7,5106 \pm 5,618$ & $0,9681 \pm 4,276$ & 0,000 \\
\hline
\end{tabular}

Tabel 6 menunjukan Hasil uji statistik didapatkan p value $0.000(\mathrm{p}<0.05)$ maka hipotesis nol (H0) ditolak, berarti ada pengaruh edukasi konsep diri terhadap peningkatan pengetahuan perkembangan remaja di SMP N 21 Semarang. dari hasil tersebut dapat dilihat bahwa pada kelompo perlakuan yang lebih efektif dalam meningkatkan pengetahuan perkembangan remaja dibandingkan dengan kelompok 
kontrolyang ditunjukkan dengan $\Delta$ mean kelompok perlakuan sebesar 7,5106 dan $\Delta$ mean kelompok kontrol 0,9681.

\section{PEMBAHASAN}

\section{Tingkat Pengetahuan Perkembangan Remaja Sebelum dan Setelah Edukasi Konsep Diri Pada Kelompok Perlakuan}

Hasil penelitian ini menunjukksn skor rata-rata sebelum diberikan edukasi konsep diri pada kelompok intervensi adalah 103,77 dengan standar deviasi 7,656. Dan rata-rata setelah diberikan edukasi konsep diri adalah 110,78 dengan standar deviasi 8,184. Artinya ada peningkatan tingkat pengetahuan perkembangan remaja dilihat dari nilai rata-rata setelah dilakukan edukasi konsep diri pada kelompok perlakuan lebih besar di banding nilai sebelum dilakukan edukasi konsep diri.

Hasil uji analisis statistika didapatkan p value $=0.000(<0.05)$ yang berarti terdapat pengaruh edukasi konsep diri untuk meningkatkan pengetahuan perkembangan remaja yang digambarkan dengan adanya perbedaan mean yang signifikan antara skor pre dan post pada kelompok perlakuan.

Edukasi atau pendidikan menurut Ivan Illich (Sholicah, 2018) adalah suatu proses dalam memberikan manusia berbagai macam situasi yang bertujuan untuk memberdayakan diri dengan mempertimbangkan berbagai aspek, yaitu aspek pencerahan, penyadaran, pemberdayaan dan perubahan perilaku. Selain itu dalam meningkatkan pengetahuan remaja perlu memperhatikan metode dan media yang digunakan. Dalam penelitian ini menggunakan metode ceramah dalam penyampaian informasi konsep diri. Menurut Notoadmojo (2010) Metonde ini dapat digunakan apabila peserta lebih dari 15 orang dan pada sasaran yang berpendidikan tinggi ataupun rendah. Adapun media dalam pendidikan kesehatan bagi berdasarkan bentuk umum dan cara produksinya.

Penelitian ini menggunakan media PPT, video dan booklet dalam proses edukasi konsep diri. Menurut penelitian Rehusisma dkk (2017) penggunaan video dan booklet memberikan penguatan dan pengetahuan baru bagi masyarakat. Sehingga hasil akhir dari edukasi konsep diri ini tingkat pengetahuan responden terhadap pengetahuan perkembangan remaja meningkat.

Apabila remaja mengetahui tentang konsep diri maka proses perkembangan remaja tersebut akan berjalan dengan baik. Remaja akan mengetahui cara berperilaku yang tepat sesuai dengan norma yang berlaku di masyarakat. Remaja juga mampu menyikapi dan menerima tentang perubahan yang terjadi dari efek perkembangannya. Ardiyanti (2017) berpendapat bahwa remaja dengan konsep diri yang positif akan mampu menampilkan sikap pribadi dan perilaku sesuai dengan aturan yang ada di lingkungannya.

Remaja dengan konsep diri yang positif mampu menilai dan memahami dirinya sendiri. Sehingga remaja menyadari kelebihan dan kekurangan yang dimilikinya. Pada aspek pertumbuhan remaja memiliki rasa percaya diri yang kurang. Apabila remaja mampu mengenali dan menerima dirinya secara utuh maka remaja akan merasa lebih percaya diri. Hal ini dikuatkan dengan pendapat Ardiyanti (2017) bahwa seseorang dengan 
konsep diri yang positif memiliki kepercayan diri dan peluang yang besar dalam menghadapi pengalaman-pengalaman yang baru dalam hidupnya

\section{Tingkat Pengetahuan Perkembangan Remaja Pada Kelompok Kontrol}

Hasil penelitian ini menunjukksn skor rata-rata sebelum pada kelompok kontrol adalah 103,57 dengan standar deviasi 7,470. Dan rata-rata setelah adalah 104,54 dengan standar deviasi 8,045. Artinya ada peningkatan tingkat pengetahuan perkembangan remaja dilihat dari nilai rata-rata setelah dilakukan edukasi konsep diri dengan hanya memberikan booklet pada kelompok kontrol lebih besar di banding nilai sebelum dilakukan edukasi konsep diri.

Hasil uji analisis statistika didapatkan $p$ value $=0.015(<0.05)$ yang berarti ada pengaruh edukasi konsep diri untuk meningkatkan pengetahuan perkembangan remaja yang digambarkan dengan adanya perbedaan mean antara skor pre dan post, yang tidak signifikan.

Edukasi konsep diri ini dilakukan pada kelompok kontrol dengan cara memberikan booklet kepada responden, bertujuan untuk memberikan informasi tentang konsep diri remaja secara tertulis kepada responden dan harapannya responden mampu secara mandiri mengenal tentang konsep diri. Namun berdasarkan hasil penelitian ini pengetahuan perkembangan remaja tidak meningkat dengan signifikan.

Pengetahuan remaja semakin berkembang apabila terpapar dengan informasi yang cukup dan metode yang tepat. Apabila remaja tidak terpapar informasi dengan metode yang tepat maka pengetahuan remaja akan buruk dan remaja tidak mengetahui apa yang seharusnya dilakukan terutama dalam segi perkembangan. Apabila pengetahuan remaja tentang perkembangannya rendah, maka remaja akan kesulitan dalam beradaptasi pada tiap-tiap tahap perkembangan dalam dirinya. Seperti pada tahap awal perubahan fisik. Remaja akan merasa tubuhnya menjadi lebih buruk. Sehingga gambaran diri remaja terhadap fisiknya akan buruk juga. Jika remaja memandang fisiknya buruk maka akan berdampak pada aspek psikologinya. Remaja cendurung merasa cemas dan khawatir tentang bentuk tubuhnya yang dianggapnya buruk. Selain itu remaja akan merasa tidak percaya diri dengan dirinya. Hasil penelitian Hasmayni (2014) didapatkan bahwa semakin tinggi kepercayaan diri maka semakin tinggi pula tingkat penyesuaian diri. Remaja memiliki rasa percaya diri yang yang tinggi, maka remaja tidak akan mengalami kesulitan dalam melakukan penyesuaian diri.

\section{Efektivitas Edukasi Konsep diri Terhadap Peningkatan Pengetahuan Perkembangan Remaja}

Berdasarkan hasil penelitian perbedaan mean selisih kelompok perlakuan dan kelompok kontrol $p$ value $0.000(\mathrm{p}<0.05)$ artinya edukasi konsep diri efektif dalam meningkatkan pengetahuan perkembangan remaja. Namun pada kelompok perlakuan menunjukkan hasil peningkatan yang signifikan dengan nilai hasil $\Delta$ mean kelompok perlakuan 7,5106. Sedangkan $\Delta$ mean kelompok kontrol 0,9681.

Perbedaan nilai $\Delta$ mean diperoleh pada kelompok perlakuan dan kelompok kontrol dipengaruhi oleh metode dan media yang digunakan dalam pelaksanaan edukasi. Pada 
kelompok perlakuan menggunakan metode ceramah dan diskusi. Dimana terdapat interaksi antara penyaji dan audiens. Sedangkan pada kelompok kontrol metode yang dilakukan hanya membagikan media yang digunakan tanpa adanya ceramah dan diskusi. Media yang digunakan pada kelompok perlakuan dalam pelaksanaan edukasi adalah berupa booklet tentang konsep diri, power point, dan video tentang konsep diri. Dan pada kelompok kontrol media yang digunakan adalah booklet tentang konsep diri.

Proses berlajar individu dalam sistem akademik dapat mempengaruhi konsep dirinya. Disini remaja banyak berinteraksi dengan teman-temannya dan menyerap pengetahuan yang diberikan oleh guru. Muhith (2015) berpendapat bahwa konsep diri terbentuk melalui sebuah proses pembelajaran seiring terjadinya pertumbuhan individu. Konsep diri sendiri tidak akan pernah lepas dari proses tumbuh kembang individu, terutama pada sisi kepribadian (Ardiyanti,2017).

Pengetahuan dapat diperoleh dari edukasi atau pendidikan kesehatan yang membutuhkan pemahaman yang mendalam dan penerimaan informasi yang baru diperkenalkan. Konsep diri dipelajari melalui kontak sosial dan pengalaman berhubungan dengan orang lain (Saraswati dkk ,2015). Apabila informasi tentang konsep diri terpapar sejak dini maka harapan kedepan remaja memiliki konsep diri yang baik dan positif.

Secara umum konsep diri sangat penting dalam perkembangan remaja. Dalam pelaksanaan tugas-tugas perkembangan remaja konsep diri perlu dikenalkan sejak dini. Menurut pendapat saya, seiring bertambahnya pengetahuan perkembangan remaja dengana konsep diri, maka dalam melaksanakan tugas-tugas perkembangan, remaja akan siap dan mudah beradaptasi dalam menjalankan masing-masing tugas perkembangan. Havighurst berpendapat bahwa terdapat 10 tugas-tugas perkembangan remaja yang harus dilaksanakan dalam proses perkembangan (Ardiyanti,2017).

Aspek konsep diri yang berperan penting dalam proses perkembangan remaja adalah identitas diri dan peran diri. Jika remaja mampu memahami tentang identitas diri dan peran diri maka remaja akan dapat mengenali dirinya secara utuh. Remaja yang mengetahui identitas dirinya akan mengenali kekuatan dan kelemahan dalam diri remaja (Ardiyanti,2017). Salah satu aspek tugas perkembangan remaja adalah remaja mampu mencapai peranan sosial sesuai dengan jenis kelamin masing-masing. Apabila remaja mengetahui peran dan identitas dirinya dengan baik maka akan timbul keselarsan dalam hidupnya (Sunaryo,2013).

Aspek lain tugas perkembangan remaja menurut Havighurst adalah remaja menerima kenyataan terjadinya perubahan fisik dan memanfaatkan fisiknya secara efektif (Ardiyanti,2017). Perubahan fisik pada remaja jika sesuai dengan pertumbuhan dan perkembangannya maka dalam pelaksanaan tugas-tigas perkembangan remaja akan berjalan dengan normal dan sewajarnya (Maiyuniati,2014). Masa remaja individu lebih fokus terhadap fisiknya. Pada masa remaja awal terjadi perubahan fisik yang signifikan dan cepat. Sikap yang di cerminkan remaja sebagai respon perubahan fisiknya secara sadar dan tidak sadar dapat menggambarkan gambaran diri atau body image dari remaja sendiri. Cara pandang remaja terhadap dirinya sendiri dapat mempengaruhi aspek 
psikologi remaja dan akan berdampak pada harga diri remaja (Sunaryo, 2013). Remaja mungkin akan minder jika perubahan fisik yang terjadi pada dirinya tidak sesuai dengan harapan. Maka apresiasi remaja terhadap dirinya sendiri menjadi rendah dan timbulah harga diri yang rendah (Sunaryo,2013). Tercermin bahwa edukasi konsep diri ini efektif dalam meningkatkan pengetahuan perkembangan remaja dapat meningkat.

\section{SIMPULAN DAN SARAN \\ Simpulan}

Pada analisis uji wilcoxon didapatkan $p$ value 0,000 pada kelompok perlakuan dan $p$ value 0,015 pada kelompk kontrol yang berarti kedua intervensi ini dapat meningkatkan pengetahuan perkembangan remaja. Sedangkan pada analisa uji mann-whitney didapatkan $p$ value 0,000 yang berarti terdapat perbedaan yang signifikan antara kedua kelompok, dan hasil $\Delta$ mean kelompok perlakuan 7,5106 dan $\Delta$ mean kelompok kontrol 0,9681, sehingga intervensi pada kelompok intervensi lebih efektif dibandingkan kelompok kontrol.

\section{Saran}

Perlu dilakukannya edukasi konsep diri pada remaja awal, hal ini diharapkan agar remaja lebih mengerti tentang konsep dalam dirinya sesuai dengan tahap perkembangannya. Bagi Institusi Pendidikan disarankan dalam memberikan kegiatan pembelajaran tentang konsep diri sehingga pengetahuan perkembangan siswa dapat meningkat dan berjalan dengan baik sesuai dengan proses perkembangan. Penelitian selanjutnya disarankan untuk mengembangkan penelitian menjadi lebih spesifik terhadap konsep diri dan perkembangan remaja.

\section{REFERENSI}

Ali, Mohammad dan Muhammad Asrori. 2008. Psikologi Remaja: Perkembangan Peserta didik. Jakarta: Bumi Aksara.

Ardiyanti, Niken. 2017. Peran Penting Konsep Diri Dalam Membentuk Track Record. Jakarta: Salemba Himanika.

Arikunto, S. 2008. Prosedur Penelitian Suatu Pendekatan Praktek. Jakarta: Rineka Cipta.

Badan Pusat Statistik Kota Semarang. 2017. Penduduk Menurut Kelompok Umur dan Jenis Kelamin. Semarang: BPS Semarang kota.

Badan Pusat Statistik Provinsi Jawa Tengah. 2018. Penduduk Menurut Kelompok Umur dan Jenis Kelamin Provinsi Jawa Tengah. Semarang: BPS Provinsi Jawa Tengah.

Hasmayni, Bobby. Hubungan Antara kepercayaan Diri Dengan Penyesuaian Diri Remaja.Garuda. 2014. Vol. 6 (2).

Herlina.2013. Bibiliotheraphy: Mengatasi masalah anak dan remaja melalui Buku. Bandung. Pustaka Cendekia Utama.

Lawrence, A S Arul dan A. Vimala. Self-Concept and Achievment Motivation of High School Student. Conflux Journal of Education. 2013. Vol 1.

Kumalasari, Pangestika W.K. dan Diyan Yulia W. Konsep Diri Anak Jalanan Usia Remaja Di Wilayah Semarang Tengah. Jurnal Keperawatan Jiwa. 2013. Vol. 1 (2).

Muhith, Abdul. 2015. Pendidikan Keperawatan Jiwa. Yogyakarta: Penerbit Andi. 
Notoatmodjo, Soekidjo. 2010. Promosi Kesehatan Teori Dan Aplikasi. Jakarta: Rineka Cipta.

Rehusisma, Lutfian Andyana. Dkk. Pengembangan Media Pembelajaran Booklet dan Video Sebagai Penguatan Karakter Hidup Bersih dan Sehat. Jurnal Pendidikan. 2017. Vol. 2.

Saraswati, Gita Karnia, et all. Faktor-faktor yang Mempengaruhi Konsep Diri Remaja di SMP N 13 Yogyakarta. Jurnal Ners dan Kebidanan Indonesia. 2015. Vol 3.

Sholichah, Aas Siti. Teori-Teori Pendidikan Dalam Al-quran. Jurnal Edukasi Islam Jurnal Pendidikan. 2018. Vol 7.

Sunaryo. 2013. Psikologi Untuk Keperawatan. Jakarta: ECG.

Upton, Paney. 2012. Psikologi Perkembangan. Jakarta: ECG.

Widiarti, Pratiwi Wahyu. Konsep Diri (Self Concept) dan Komunikasi Interpersonal dalam Pendampingan Pada Siswa SMP se Kota Yogyakarta. Informasi Kajian Ilmu Komunikasi. 2017; Volume 47. 